\title{
HACCP-based quality risk management approach to udder health problems on dairy farms
}

Noordhuizen JPTM ${ }^{1,2,3,4}$, Cannas da Silva $\mathrm{J}^{1}$

${ }^{1}$ VACQA-International, LMV, Lugar de Atalaia, 2005-110 Almoster, Santarém, Portugal

${ }^{2}$ Gent University, Faculty of Veterinary Medicine, Merelbeke, Belgium

${ }^{3}$ Ecole Nationale Vétérinaire de Lyon, France

${ }^{4} 378$ Rue de l'Eglise, 27450 Saint Georges-du-Vièvre, France

\section{ABSTRACT}

Against the background of prevailing udder health problems on dairy farms, this paper discusses a new approach to mastitis control. Current udder health control programmes, such as the 'five-point plan', are highlighted and their drawbacks indicated. The concept and principles of hazard analysis critical control points (HACCP) are introduced. The eight core elements of this concept are dealt with by using the example of a dairy herd with a mastitis problem due to Staphylococcus aureus. The various steps to be taken in the development of a HACCP-based quality risk management programme are illustrated through the application of core elements. Finally, it is shown that the HACCP key words, structure, organisation, planning, communication and formalisation; which do not frequently appear in conventional herd health and production management programmes can contribute to better udder health. The role of the veterinarian can be paramount and of added value, if he/she is willing to invest in new knowledge and skills, such as the HACCP concept, farm economics, animal nutrition, and particularly the role of coach to the dairy farmer in the implementation of preventative measures in relation to udder health.

KEYWORDS: dairy farms; HACCP principles; quality risk management; udder health control

\section{CORRESPONDING AUTHOR:}

JPTM Noordhuizen

378 Rue de I'Eglise, 27450 Saint Georges-du-Vièvre, France

E-mail: noordhu1@xs4all.nl

Irish Veterinary Journal

\section{INTRODUCTION}

Mastitis in dairy cows is a multifactorial disease with a long history. In addition to the associated impairment of welfare due to the pain, it is the most costly endemic disease in dairy herds with an average yearly incidence of about $28 \%$. Among the economic loss components are the loss of milk production, treatment costs, extra labour and premature culling of chronically infected cows (Huirne et al. 2002). Moreover, mastitis represents a stress factor for the farmer. Over decades, much research has been conducted in the area of udder health. Although a variety of treatment and prevention protocols have been developed over the years, success rates have been variable and a true solution to the problem has not been found. Differences in mastitis prevalence rates between farms are large (Hogeveen and Osteras 2005; Noordhuizen and Hogeveen 2005).

Regarding the potential causes of failure to solve the problem, various suggestions have been provided. Firstly, multifactorial diseases are not always easy to eliminate if adequate attention is not given to contributing causal factors, or if the pathogen is ubiquitously present in the environment. Secondly, for a proper understanding of the mastitis problem sufficient information must be available, e.g., cow history, environmental conditions, production data, management data. Thirdly, hygiene is recognised as an important issue, but farmers should understand that hygiene goes far beyond hygiene during milking alone. Hygiene at all levels should be addressed: housing, feeding, cows in the barn, milkers. Finally, when an udder health control programme (UHC) is designed and implemented, it warrants a persistent and protocol-based approach by both the farmer (and his co-workers) and a coaching veterinarian in all areas of udder health (Hancock and Dargatz 1995; Noordhuizen and Hogeveen 2005).

This paper deals with a new kind of approach to udder health problems in which all fragments of other approaches are integrated, structured and formalised: the HACCP-like Quality Risk Management approach. The objectives are to show that this approach is feasible on the dairy farm, and that its intrinsic structure, organisation, planning and formalisation may yield better results than the conventional methods.

\section{UDDER HEALTH CONTROL, UHC}

The complexity of mastitis and its control is presented in Figure 1. In addition to the herd dynamics with different 
interactions between cows, influenced by variations in housing, climate, feed quality and milking machine conditions, the impact of management issues including, for example, milking method, drug application, feeding management, hygiene practice can also have a significant affect. These complexities are further impacted by issues such as the farmer's attitude, animal welfare and the use of analgesics, and farm economics. At the output side there are several options to measure udder health in the herd directly or indirectly (e.g., somatic cell counts; bacteria counts; bacteriological culturing of mastitis samples; incidence/prevalence figures) and we can conduct monitoring and surveillance activities in the areas related to udder health and its control.

Among udder health control programmes, the five point plan issued in the 60's predominantly focussed on contagious mastitis, e.g., Streptococcus agalactiae. This scheme has proven to be rather successful (Kingwill et al. 1970; Bramley and Dodd 1984).

The five points involve clinical and subclinical mastitis, drying off therapy, the culling of chronically infected cows, the proper milking machine function, and appropriate milking methods including teat dipping. The main goals are to prevent new infections from occurring and reducing the number of existing infections. Since the 1960's this five point plan has been expanded to eight or ten points, including areas like feeding, farm hygiene and adequate housing and climate, but the principles remained the same. Total farm hygiene means that in addition to hygiene around milking (machine, milkers, waiting area, teats and teat dip), attention must also be given to overall hygiene of cows in the barn, hygiene of cubicles, exercise areas, equipment and feed bunk. All these activities together are not easy to persistently conduct on a farm.

After applying an UHC programme, the pathogen profile of dairy herds usually change. Coliform bacteria have emerged in low cell count herds where streptococci have been

\section{THE HERD DYNAMICS}

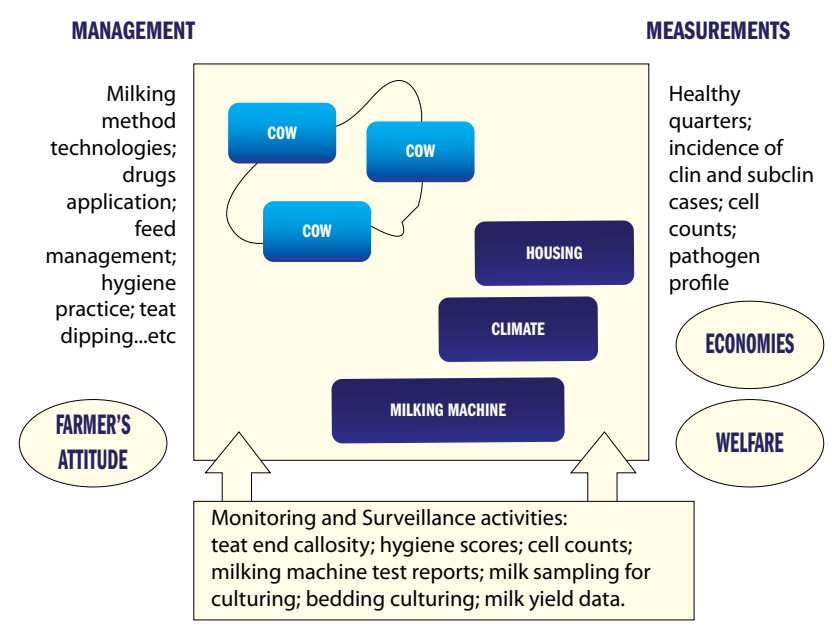

Figure 1: A schematic view on the complexity of mastitis problems in dairy herds and elements of control. reduced, indicating udder infections due to environmental bacteria challenging the immune responsiveness of high yielding cows (Schukken et al. 2005). Impaired immuneresponsiveness is at the same time linked with an increased milk yield and negative energy balance (NEB) after calving and ketosis (Suriyasathaporn et al. 2000). Control measures are usually focussed on improving the immune-responsiveness of cows by reducing the NEB and ketosis, and optimising cow comfort issues (Noordhuizen and Lievaart 2005). Staphylococcus aureus as a third major udder pathogen group plays an intermediate role between contagious and environmental bacteria. This pathogen has various subtypes, each with its own epidemiological herd dynamics (Zadoks et al. 2002).

The reliability of information about the udder health situation on a dairy farm is at best variable. This variability can occur due to a higher or lower availability of such information, but also due to bias in, for example, the farmer or veterinarian's observational skills. Moreover, laboratory testing results may show bias, due to variation in sensitivity and or specificity of diagnostic tests; there is quite a difference in results when comparing bacteriological culturing and DNA-fingerprinting results. Any bias may lead to misclassification and misinterpretation, either negative or positive, which in their turn lead to improper UHC measures.

Finally, there is the matter of ensuring that all measures are consistently implemented in full and advice offered to the farmer as required. This is about communication and coaching. Given the complexity of udder health problems it is paramount that the farmer understands the different risk factors and their impact and that the veterinarian is a member of the problem solving team. In addition to technical advice, communication qualities (empathy, emotion, perception, attitude, voice and tone of speaking) are paramount to the success of control programmes. It seems that too often the farmer does not quite understand the relevance of risk factors and measures to be taken, while on the other hand, the veterinarian too often leaves the farmer alone with his problem, without playing his role as a coach.

\section{HACCP: CONCEPT AND APPLICATION}

HACCP addresses product quality through the control of the production process. It was originally developed for the NASA space programme to safeguard astronauts from chemical, physical and micro-biological hazards through food. For a history and review, see Pierson (1995) and Hulebak and Schlusser (2002).

The HACCP concept and principles have been adopted by the EU for safeguarding consumers from food safety hazards through the food producing industries. Moreover, in 2004 the EU has suggested that farmers implement a HACCPlike programme on their farm to control hazards and risks in the areas of food safety and public health, and animal health and welfare, as part of the new Hygiene directive EC 852/853/854-2004 (Noordhuizen et al. 2007).

The eight key components in the HACCP concept and principles, and hence in the handbook of HACCP-like Quality Risk Management programmes are: analysis of main hazards 
and associated risks on a farm (e.g., mastitis); production process diagrams (e.g., a more detailed elaboration of Figure 1); definition of critical control points (CCPS) with their standards and tolerance limits, and points of particular attention (POPA) with their targets; the monitoring of these CCP's and POPA's; the availability of corrective measures; working instructions and guidelines; records; verification (Cullor 1995; Noordhuizen and Welpelo 1996).

In the next section the example of a herd mastitis problem due to Staphylococcus aureus is addressed by following several of the eight key components highlighted above.

\section{Hazard identification}

The main hazard, Staphylococcus aureus is identified in this step. Based on a herd inventory and history, a herd treatment advisery plan is designed, comprising several categories of disease severity groups (e.g. mild; severe; very severe mastitis), and the actions or interventions (including drug choice, dosage, route of administration and withdrawal period). Problem cows are identified based on a set of criteria (e.g. mastitis history, repeat cases, cure rate, cell count levels). Next step is the identification of risk factors for Staphylococcus aureus, applicable to this particular farm. These risk factors are listed in Table 1.

Regarding the CCP's and POPA's it can be stated that formal HACCP programmes comprise CCP's which have to meet different formal criteria; if those criteria are not met, one can decide to retain that point as a point of particular attention (POPA). The criteria most frequently not met are: a full restoration of process control after corrective measures are taken; and: the presence of formal standards and tolerance limits. In physical processes (e.g., industry) most if not all control points are CCP; in live animals with their biological variation we will most often deal with POPA's. Regarding the definition of CCP's and POPA's, the following action was taken.

The risk factors from Table 1 were weighted and ranked in order of estimated relevance. Weighting can be done quantitatively using odds ratios, semi-quantitatively using the procedure of adaptive conjoint analysis (Angus et al. 2005), or qualitatively by making a best possible estimate (Noordhuizen et al. 2007). Then, each of them were screened for CCP or POPA, provided with standard/ tolerance limits or a target respectively and positioned in the monitoring scheme. The latter includes: CCP or POPA, method of monitoring, frequency of monitoring, person responsible of monitoring, result of monitoring (Table 2).

The targets are for example: the envisaged yearly incidence

Table 1: Risk factors contributing to Staphylococcus aureus mastitis on the example farm. Figures in brackets refer to the weighting and ranking of the risk factors

\begin{tabular}{|l|l|}
\hline Deficiencies in the milking machine function & $(1)$ \\
\hline High teat end callosity scores in the herd & $(2)$ \\
\hline $\begin{array}{l}\text { Contaminated hands of milkers, bedding material, flies } \\
\text { Previous udder infections with Staphylococcus aureus or } \\
\text { Streptococcus uberis }\end{array}$ & $(3)$ \\
\hline Poor milking method and hygiene & $(4)$ \\
\hline Poor culling policy regarding problem cows & $(5)$ \\
\hline Age of cows & $(6)$ \\
\hline
\end{tabular}

rate of clinical mastitis cases $(<25 \%)$; the somatic cell counts at cow level $(<150.000 / \mathrm{ml})$; the level of new udder infections per time unit $(<10 \%)$.

Each of the items listed under 'Risk area' in Table $\mathbf{2}$ should be further detailed to be as specific as possible. For example, if the farmer considers daily which cows should be defined as problem cows; he considers once a week which problem cows should be culled or treated.

Zadoks (1999) has examined the decision dilemma that surrounds treating or culling. An older cow, 150 days in lactation with subclinical mastitis in both hind quarters due to Staphylococcus aureus, an average somatic cell count level of 2 million/ml would better be culled than treated because expected cure rate is around $1 \%$. In contrast, a young cow with mastitis in one front quarter and a somatic cell count of $500,000 / \mathrm{ml}$ and 220 days in lactation would have an expected cure rate of around $60 \%$. Various economic assessments about treating mastitis or not have been published (Swinkels et al. 2005).

Results of each monitoring action are recorded on a monitoring log with date and findings; when deviations have been noticed, the intervention conducted is recorded too. An intervention plan for this example farm could comprise the elements, as listed in Table 3.

Table 2: Hazards and risks listing (with CCP and POPA, standards or targets, monitoring)

\begin{tabular}{|c|c|c|c|}
\hline Risk area: & $\begin{array}{l}\text { CCP or } \\
\text { POPA }\end{array}$ & Target & Monitoring \\
\hline $\begin{array}{l}\text { Milking machine function (e.g. } \\
\text { vacuum level) }\end{array}$ & POPA & Optimal & $\begin{array}{l}\text { Daily }+1 \mathrm{x} / \\
\mathrm{wk}+2 \mathrm{x} / \mathrm{yr}\end{array}$ \\
\hline Teat liner condition & POPA & Optimal & $1 x / w k$ \\
\hline $\begin{array}{l}\text { Overall hygiene on the farm (e.g. } \\
\text { barn) }\end{array}$ & POPA & Optimal & $1 x / w k$ \\
\hline $\begin{array}{l}\text { Udder health state (pathogen } \\
\text { profile) }\end{array}$ & POPA & Optimal & $\begin{array}{l}\text { Daily + 1x/ } \\
\text { wk }\end{array}$ \\
\hline $\begin{array}{l}\text { Milking method and hygiene (+ } \\
\text { milker) }\end{array}$ & POPA & Optimal & Daily \\
\hline Culling rate of problem cows & POPA & Optimal & $\begin{array}{l}\text { Daily + 1x/ } \\
\text { wk }\end{array}$ \\
\hline
\end{tabular}

Note that 'Optimal' means according to prescriptions of the manufacturer or at best possible practice (e.g., Bray and Shearer 1994).

The proposed interventions (corrective measures) are described on a separate sheet and updated when needed, e.g., after a follow-up evaluation.

The working instructions (WI) as indicated in Table $\mathbf{3}$ (herd treatment advisery plan; instruction on milking method and hygiene; criteria for culling) can be considered as technical management tools. They are meant to avoid flaws in attention and lack of compliance. It has been proven that such working instructions are highly beneficial and economically justified for the dairy farmer (Animal Health Service 2006). Working instructions are detailed elaborations of (parts of) good dairy farming (GDF) codes of practice, which are general guidelines to improve attitude and mentality of people working on the farm (OIE 2006). Examples are: good milking hygiene, good medicine application (Noordhuizen et al. 2007). 
Records in a HACCP-like Quality Risk Management programme must be functional for operational farm management to maintain motivation of the farmer. They must also be relevant with regard to HACCP demands. In the latter case, such records must allow the internal validation of the HACCP-like Quality Risk Management programme to ensure it is functioning properly, as well as meeting the demands of HACCP with regard to demonstrating the herd status and measures taken for improvement of animal health and welfare, public health and food safety. In summary, the following records

Table 3: Intervention and advice plan for the example farm

\begin{tabular}{|c|c|c|}
\hline Activities to be undertaken & WI & Responsible \\
\hline \multicolumn{3}{|l|}{ Short term: } \\
\hline $\begin{array}{l}\text { 1. Keep milking machine in good function at all } \\
\text { times (frequent check-ups; maintenance; machine } \\
\text { evaluation) }\end{array}$ & WI & Farmer \\
\hline $\begin{array}{l}\text { 2. Adjust milking method and improve milking } \\
\text { hygiene }\end{array}$ & WI & Farmer(V) \\
\hline \multicolumn{3}{|l|}{$\begin{array}{l}\text { 3. Follow the herd treatment advisory plan for } \\
\text { diagnosis and treatment of mastitic cows }\end{array}$} \\
\hline $\begin{array}{l}\text { 4. Cull chronically infected cows according to } \\
\text { criteria }\end{array}$ & WI & Farmer (V) \\
\hline $\begin{array}{l}\text { 5. Monitor healthy and infected cows and the } \\
\text { environment }\end{array}$ & & Farmer, Vet \\
\hline \multicolumn{3}{|l|}{ Long term: } \\
\hline 1. Implement separate housing for mastitis cows & & Farmer \\
\hline $\begin{array}{l}\text { 2. Improve cow comfort elements (feeding, housing, } \\
\text { climate) }\end{array}$ & & Farmer (V) \\
\hline 3. Improve overall farm hygiene & & Farmer (V) \\
\hline
\end{tabular}

are core components: general farm information sheet; hazards and risks sheet (including risk weighting, true risk identification, СCP and POPA determination); monitoring scheme (including the CCP's and POPA's, their standards and tolerance limits, or target values respectively, the method, frequency and person responsible for monitoring); the monitoring results sheet (including CCP's and POPA's monitored with date and findings, and in the case of deviations, the corrective measures taken); the GDF guidelines and working instructions; a list of monthly, six or 12-monthly herd performance figures; checklists for internal validation; reports of external verification audits (Noordhuizen et al. 2007).

\section{DISCUSSION AND CONCLUSIONS}

Several remarks may be made in relation to the creation of a formal HACCP-based Quality Risk Management (QRM) programme handbook. Firstly, this type of QRM represents a highly structured and organised approach. Planning and prevention are fully protocol-based. Such aspects are often lacking in conducting veterinary UHC or herd health and production management programmes (Brand et al. 1996; De Kruif et al. 2007). Secondly, there are quite some elements in this QRM approach which may look familiar because they also appear in herd health and production management programmes. Examples are risk assessment, monitoring, record keeping, performance figures, and interventions. However, the major difference between the two approaches is the emphasis placed on structure, planning, organisation, and formalisation present in QRM. However, there are similarities between the two approaches and it is possible to integrate the two into a single advisery programme for the dairy farmer. In that way, the operational management issues and the more tactical quality risk control can be addressed simultaneously.

With a focus on UHC problems, the HACCP-like approach wil focus the farmer's attention on relevant areas. In QRM, all areas must be addressed at the same time, and preferably in an extensive manner. Guidance is provided by a coaching veterinarian and the records of the HACCP handbook. These records provide the means to focus on relevant areas. In fact, farmers who have experienced the implementation of HACCP principles are much more focused and motivated to solve a herd problem as the whole picture is more clear (Valeeva et al. 2007). In addition to this, the HACCP-like QRM provides the veterinarian with means to act as a coach for the farmer, once the veterinarian has acquired the necessary knowledge and skills, of which adequate communication is one of the most important (Noordhuizen and Metz 2005; Cannas et al. 2006). Other important domains of new knowledge are farm economics, animal nutrition, marketing and business administration.

HACCP is one method among other quality control concepts. Other concepts include good manufacturing practice and international standardisation organisation concepts (e.g., ISO 9000 , ISO 14000 and ISO 22000). It has been determined earlier that the HACCP approach is best applicable to (dairy)

Table 4: The 12-steps scheme for developing a HACCP-based Quality Risk Management (QRM) programme (adapted after Cullor 1995)

\begin{tabular}{|l|l|}
\hline Step 1 & $\begin{array}{l}\text { Assemble an on-farm QRM-team; describe the general farm } \\
\text { geography. }\end{array}$ \\
\hline Step 2 & $\begin{array}{l}\text { Identify the most significant hazards in public health and food } \\
\text { safety, and in animal health and animal welfare. }\end{array}$ \\
\hline Step 3 & $\begin{array}{l}\text { Determine the risk factors associated with the defined main } \\
\text { hazards, and explore which are applicable on the particular dairy } \\
\text { farm. }\end{array}$ \\
\hline Step 4 & $\begin{array}{l}\text { Draw farm process flow diagrams (general and detailed for a } \\
\text { hazard) and check these on site. }\end{array}$ \\
\hline Step 5 & $\begin{array}{l}\text { Define critical control points (CCP), and points of particular } \\
\text { attention (POPA). }\end{array}$ \\
\hline Step 6 & $\begin{array}{l}\text { Determine the respective standards and tolerance limits (CCP) } \\
\text { and target values (POPA). }\end{array}$ \\
\hline Step 7 & $\begin{array}{l}\text { Weigh the different risk factors for their probability of occurrence } \\
\text { and their impact. }\end{array}$ \\
\hline Step 8 & $\begin{array}{l}\text { Design a formal monitoring scheme, including CCP/POPA, method } \\
\text { of monitoring, frequency of monitoring, person responsible, } \\
\text { measures to be taken at deviations. }\end{array}$ \\
\hline Step 9 & $\begin{array}{l}\text { Determine sets of corrective measures for deviations occurring at } \\
\text { CCP's and or POPA's. }\end{array}$ \\
\hline Step 10 & $\begin{array}{l}\text { Develop good dairy farming guidelines and technical working } \\
\text { instructions for areas needing particular attention. }\end{array}$ \\
\hline Step 11 & $\begin{array}{l}\text { Introduce the necessary documents and install specific training } \\
\text { programmes of short duration for farm workers. } \\
\text { Install internal validation procedures, and external auditing } \\
\text { procedures. }\end{array}$ \\
\hline Step 12 &
\end{tabular}


farms because it is highly farm-specific, with relatively low labour and costs input, fit for integration in food chain quality assurance programmes and for certification. Also, the herd status with regard to animal health and welfare, and public health and food safety can be demonstrated as well as improvement measures taken (Cullor 1995; Noordhuizen and Welpelo 1996). The concept and seven principles are integrated into a 12-step scheme for developing a HACCPlike Quality Risk Management programme on dairy farms (Table 4, adapted after Cullor 1995). Further information and detailed elaborations of this QRM can be found at www. vacqa-international.com and in Noordhuizen et al. (2007). Veterinarians who want to enter this new field of approach will - after acquiring the proper knowledge, skills and experience - prove their added value to dairy farmers and the dairy sector, and hence will fulfil their role of intermediate between the dairy (farming) sector and society.

\section{REFERENCES}

Angus L, Bowen H, Gill LAS et al. (2005) The use of conjoint analysis to determine the importance of factors that affect on-farm welfare of the dairy cow. Animal Welfare 14 (3), 203-213.

Animal Health Service (2006) Effects of guidelines and working instructions, a three-year study on 1000 dairy farms. Animal Health Service, Deventer, The Netherlands.

Bramley AJ, Dodd FH (1984) Reviews of the progress of dairy science: mastitis control (progress and prospects). Journal of Dairy Research 51, 481-512.

Bray DR, Shearer JK (1994) Milking machine and mastitis control handbook. Cooperative Extension Service, IFAS circular 1136, University of Gainesville, Florida, USA.

Brand A, Noordhuizen JPTM and Schukken YH (1996) Herd health and production management in dairy practice. Wageningen Academic Publishers, Wageningen, The Netherlands.

Cannas J, Noordhuizen JPTM, Vagneur M et al. (2006) The future of veterinarians in bovine health management. In: Proceedings of the World Buiatrics Congress (Navetat \& Schelcher) (eds). Nice, France, October 2006.

Cullor JS (1995) Implementing the HACCP programme on your clients' dairies. Veterinary Medicine/ Food Animal Practice, March, 290-295.

De Kruif A, Mansfeld R and Hoedemaker M (2007) Tierärztliche Herdenbetreuung beim Milchrind. 2nd edn. Enke Verlag, Stuttgart, Germany.

Hancock D, Dargatz D (1995) Implementation of HACCP on the farm. In: Proceedings of a Symposium on HACCP, 75th Meeting of Research Workers in Animal Diseases, November 12, 1995, Chicago, III., USA.

Hogeveen H, Osteras O (2005) Mastitis management in an economic framework. In: Mastitis in Dairy Production. Proceedings of the 4th IDF International Conference (H.Hogeveen, editor), 41-52, Maastricht, The Netherlands, 11-16 June 2005, Wageningen Academic Publishers, Wageningen, The Netherlands.

Huirne RBM, Saatkamp HW and Bergevoet RHM (2002) Economic analysis of common health problems in dairy cattle. In: Proceedings of the XIIth World Buiatrics
Congress (Kaske, Scholz \& Holtershinken, editors), 18-23 August 2002, Hannover, Germany, 420-431.

Hulebak KL, Schlusser W (2002) HACCP history and conceptual overview. Risk Analysis 22 (3), 547-552.

Kingwill RG, Neave FK, Dodd FH et al. (1970) The effect of a mastitis control system on levels of clinical and subclinical mastitis in two years. The Veterinary Record 84, 94-100.

Noordhuizen JPTM, Welpelo HJ (1996) Sustainable improvement of animal health care by systematic quality risk management according to the HACCP concept. The Veterinary Quarterly 18, 121-126.

Noordhuizen JPTM, Hogeveen H (2005) The systems approach to udder health control. In: Mastitis in Dairy Production, Proceedings of the 4th IDF International Mastitis Conference. Hogeveen $\mathrm{H}$ (ed). 551-558, Maastricht, The Netherlands, 11-16 June 2005, Wageningen Academic Publishers, Wageningen, The Netherlands.

Noordhuizen JPTM, Metz JHM (2005) Quality control on dairy farms with emphasis on public health, food safety, animal health and welfare. Livestock Production Science 94 (1-2), 51-59.

Noordhuizen JPTM, Lievaart JJ (2005) Cow comfort and Cattle Welfare. In: Proceedings of Buiatrissima, the 1st Swiss Buiatrics Association Congress, Bern, $(\mathrm{CH}), 7-12$.

Noordhuizen JPTM, Cannas da Silva J, Boersema JSC et al. (2007) Applying HACCP-based Quality Risk Management on Dairy Farms. Wageningen Academic Publishers, Wageningen, The Netherlands.

OIE, Office Internationale des Epizooties. (2006) Guide to good farming practices for animal production food safety. Rev. sci. techn. OIE 25 (2) 823-836.

Pierson M (1995) An overview of HACCP and its application to animal production food safety. In: Proceedings of the Symposium on Hazard Analysis Critical Control Points, Conference of Research Workers in Animal Diseases, November 12, 1995, Chicago, III. USA

Suriyasathaporn W, Heuer C, Noordhuizen-Stassen EN et al. (2000) Hyperketonaemia and the impairment of udder defense: a review. Vet. Research 31, 397-412.

Swinkels JM, Zadoks RN and Hogeveen H (2005) Use of partial budgetting to determine the economic benefits of antibiotic treatment during lactation of chronic mastitis caused by Staphylococcus aureus. In: Mastitis in Dairy Production, 217-224, Proceedings of the 4th IDF International Mastitis Conference, Maastricht, The Netherlands, 11-16 June 2005, Wageningen Academic Publishers, Wageningen, The Netherlands.

Valeeva NI, Lam TJGM and Hogeveen H (2007) Motivation of dairy farmers to improve mastitis management. Journal of Dairy Science (in press).

Schukken YH, Tikofsky LL and Zadoks RN (2005) Environmental control for mastitis prevention, milk quality and food safety. In: Proceedings of the 4th IDF International Mastitis Conference (H.Hogeveen, editor), Maastricht, June 2005, pages 109-114, Wageningen Academic Publ., Wageningen, The Netherlands.

Zadoks RN (1999) Personal communication.

Zadoks RN, Allore HG, Hagenaars TJ et al. 2002 A mathematical model of Staphylococcus aureus control in dairy herds. Epidemiology \& Infection, 129, 397-416. 